\title{
ARTIGOS \\ Detached wheat leaf assay for assessing the sensitivity of Puccinia triticina races to fungicides
}

\author{
Camila Turra $^{1,2}$, Erlei Melo Reis ${ }^{2}$ e Amarilis Labes Barcellos ${ }^{1}$
}

${ }^{1}$ OR Melhoramento de Sementes Ltda, Passo Fundo, RS. Email, ${ }^{2}$ Universidade de Passo Fundo (UPF) - Passo Fundo, RS. Endereço atual OR
Sementes Ltda. Passo Fundo, RS
Autor para correspondência: Erlei Melo Reis. (erleireis@upf.br)

Data de chegada: 11/04/2014. Aceito para publicação em: 18/09/2014.

$10.1590 / 0100-5405 / 1992$

\section{ABSTRACT}

Turra, C.; Reis, E. M.; Barcellos, A. L. Detached wheat leaf assay for assessing the sensitivity of Puccinia triticina races to fungicides. Summa Phytopathologica, v.43, n.3, p.181-185, 2017.

In experiments conducted in a growth chamber and in laboratory, the preventive, curative and eradicative action of fungicides was assessed for the control of Puccinia triticina races MFT-MT and TFP-HT. The effect of fungicides tebuconazole (triazole) and azoxystrobin (strobilurin) was evaluated separately. Seedlings were inoculated with a suspension of $50 \times 10^{3}$ uredospores $/ \mathrm{mL}$ distilled water added of $120 \mu \mathrm{L}$ adjuvant (polyoxyethylene sorbitan monolaurate Tween 20 - Synth). Fungicides were applied 24 hours before inoculation (preventive control), 96 hours after inoculation (curative control) and ten days after inoculation (eradicative control), both in seedlings (in vivo) grown in pots and in leaf segments (in vitro) on Petri dishes. The effect of treatments based on the number of uredia/ $/ \mathrm{cm}^{2}$ and the production of uredospores/uredium were tested in vivo and in vitro. When applied preventively, for both races, the two fungicides controlled $100 \%$ leaf rust, and when applied curatively, only azoxystrobin led to $100 \%$ control. The tested races remain sensitive to azoxystrobin but maintain the reduction in sensitivity to tebuconazole. Detached wheat leaf assay was efficient in assessing the sensitivity of $P$. triticina races to fungicides and leaves remained green for 18 days.

Keywords: Leaf rust, fungicide resistance, Triticum aestivum.

\section{RESUMO}

Turra, C.; Reis, E. M.; Barcellos, A. L. Sensibilidade de raças de Puccinia triticina, a fungicidas determinada em folhas de trigo destacadas. Summa Phytopathologica, v.43, n.3, p.181-185, 2017.

Em experimentos conduzidos em câmara climatizada e laboratório, quantificou-se a ação preventiva, curativa e erradicativa dos fungicidas no controle das raças MFT-MT e TFP-HT de Puccinia triticina. Avaliou-se o efeito dos fungicidas tebuconazol (triazol) e azoxistrobina (estrobilurina), isoladamente. As plântulas foram inoculadas com uma suspensão de $50 \times 10^{3}$ uredosporos/ $\mathrm{mL}$ de água destilada adicionada de $120 \mu \mathrm{L} / \mathrm{L}$ de adjuvante (polioxietileno sorbitano monolaurato Tween 20 - Synth). Os fungicidas foram aplicados, 24 horas antes da inoculação (controle preventivo), 96 horas após a inoculação (controle curativo) e dez dias após a inoculação (controle erradicativo), tanto nas plântulas (in vivo) cultivadas em vasos como nos segmentos foliares (in vitro) em placas de Petri. Avaliou-se o efeito dos tratamentos em função do número de urédias $/ \mathrm{cm}^{2}$ e a produção de uredosporos/urédia, in vivo e in vitro. Os fungicidas aplicados preventivamente, para ambas as raças, controlaram $100 \%$ a ferrugem da folha e curativamente somentre a azoxistrobina. As raças testadas permanecem sensíveis à azoxistrobina, porém, mantendo a redução da sensibilidade ao tebuconazole. O método de folhas de trigo destacadas foi eficiente na avaliação da sensibilidade de raças de $P$. triticina a fungicidas tendo as folhas permanecido verdes por 18 dias.

Palavras-chave: Ferrugem da folha, resistência a fungicidas, Triticum aestivum.

Instability in Brazilian wheat (Triticum aestivum L.) production is mainly due to constant oscillation in the market price, high production cost and disease occurrence. In 2010/2011 season, the acreage was 2 million and 150 thousand hectares, while in 2011/12 season a $20 \%$ increase in domestic wheat production was expected (5).

Leaf rust, caused by Puccinia triticina (Pt) Ericks, is one of the most important diseases affecting wheat in all regions where the cereal is grown $(4,12)$. Grain yield of susceptible cultivars is severely affected by rust, which requires the use of fungicides, increasing the production cost and leading to disuse of these genotypes.

Damage due to leaf rust can be estimated based on the normalized function $\mathrm{Y}=1,000-6.4 \mathrm{I}(\mathrm{Y}=$ normalized yield $\mathrm{kg} / \mathrm{ha}$ and $\mathrm{I}=$ leaf incidence) (11).

Cultivars that are genetically resistant to leaf rust have been recommended by Brazilian wheat breeding programs. However, most of them were based on a few resistance genes and, due to the variability of the fungus, are easily outdated. Therefore, the use of fungicides on above-ground organs has become a recommended practice (11)

The preventive, curative and eradicative action of fungicides is not adopted as a criterion to decide the first fungicide application time to control the disease (11). According to Hewitt (8), the preventive action of a fungicide occurs when it is applied on healthy tissues (prepenetration); the curative action occurs when it is applied after fungal penetration but before symptom/sign emergence (pre-symptom/sign); and the eradicative action occurs when it is applied after the onset of symptoms (post-symptoms/signals). In the present paper, the terms relating to fungicide action were used according to the concepts of Hewitt (8). 
In 2005 wheat growing season, reports of failure in wheat leaf rust control by traditionally used fungicide treatments warned farmers and technicians about a possible reduction in $P t$ sensitivity to fungicides of the triazole group $(1,3)$.

A pioneer study was conducted at the Plant Pathology Laboratory of University of Passo Fundo and at the Rust Laboratory of OR Seed Improvement Ltd, Passo Fundo, in 2006-2008 seasons, to assess the sensitivity of races to triazoles and strobilurin and their mixtures. Fungicides were tested against four Pt races: MCG-MN, considered sensitive to all fungicides and identified in 1989, and races MDT-MR, MFP-CT and MDP-MR, with sensitivity shift identified in 2005, 2006 and 2007, respectively. Results showed that the four fungal races were sensitive to strobilurins and their mixtures at different application times. However, MDT-MR, MFT-CT and MDP-MR showed sensitivity reduction to triazoles $(1,3)$.

Subsequently, Bianchin (3) monitored the sensitivity of new Pt races detected in 2008 and 2009 seasons to the same triazole fungicides and showed the reduced sensitivity of the new races (TDP-MR, TDP-HR, TPT-HT, and MDP-MT) to demethylation inhibitor (DMI) fungicides.

These studies were performed by sowing wheat seedlings in polyethylene pots in a greenhouse. The detached wheat leaf method could also be adapted, since it is conducted in Petri dishes which were kept in a growth chamber (Biological oxygen demand), optimizing space, reducing costs and labor, and better controlling environmental conditions such as temperature and light.

As the fungal population evolves resulting in new races every year, the sensitivity of new populations to fungicides applied to control rust must be monitored.

This study aimed to evaluate the sensitivity of $P t$ races MFT-MT$4002 \mathrm{~S}$ and T(F)P-HT to fungicides, inoculated in wheat cultivars 'Ônix' and 'Quartzo', respectively, in order to implement the detached leaf assay to monitor their sensitivity to fungicides.

\section{MATERIAL AND METHODS}

\section{Seedling cultivation}

Plants were cultivated in polyethylene pots containing $300 \mathrm{ml}$ soil supplemented with poultry litter. Twenty seeds were sown in each pot, with four replicates, serving as a source of seedlings for the in vivo and in vitro experiments. After emergence, seedlings were thinned to ten plants per pot. Plants were maintained at $20^{\circ} \mathrm{C} \pm 2{ }^{\circ} \mathrm{C}$ and $12 \mathrm{~h}$ photoperiod. Kristalon fertilizer compound (100 g/5 L water), $5 \mathrm{ml}$ per pot, was applied on the seventh day after sowing.

\section{Detached wheat leaf preparation}

Three leaf segments per plastic Petri dish ( $9 \mathrm{~cm}$ diameter) were deposited on an aluminum foil and with a spatula the ends were introduced into the culture medium [ $8 \mathrm{~g}$ agar, $0.3 \mathrm{~g}$ streptomycin sulfate, benzimidazole salt ( $98 \%$, diluted $10.2 \mathrm{~g} / 100 \mathrm{ml}$ water), 1,500 $\mu \mathrm{g} / \mathrm{L}$ distilled water].

\section{Inoculum multiplication}

Races MFT-MT 4002S and T(F)P-HT were most frequent and virulent in 2011 growing season. The inoculum was supplied by OR Seed Improvement Ltd, Leaf Rust Laboratory, and was multiplied by means of inoculation in 'Ônix' and 'Quartzo' cultivars, respectively. Plants were kept in a growth chamber (at $20{ }^{\circ} \mathrm{C} \pm 2{ }^{\circ} \mathrm{C}$ and $12 \mathrm{~h}$ photoperiod). Ten days after sowing, a uredospore suspension of the two races in mineral oil (Soltrol) was sprayed onto seedling leaves. After inoculation, seedlings were transferred to a chamber in the dark, at $20{ }^{\circ} \mathrm{C} \pm 2{ }^{\circ} \mathrm{C}$ and $95-100$ relative humidity. Leaves were wet by spraying distilled water plus $120 \mu \mathrm{L} / \mathrm{L}$ adjuvant (Tween 20) and covered with transparent plastic. Twenty hours after inoculation, the incubation period ended, and the $12 \mathrm{~h}$ photoperiod was restored, maintaining the plastic cover for 72 hours at $20^{\circ} \mathrm{C} \pm 2{ }^{\circ} \mathrm{C}$, to keep the leaves wet.

Fourteen days after inoculation, uredospores produced by pustules were collected with a vacuum pump, deposited in gelatin capsules and immediately used in the inoculations to keep high germination and achieve the desired viable uredospore concentration.

\section{Inoculation}

Inoculum density was $5 \times 10^{4}$ uredospores $/ \mathrm{mL}$ distilled water. MFT-MT race was inoculated in 'Ônyx' and TFP- HT in 'Quartzo' at the first expanded leaf stage 11, twelve days after sowing, (13) and in the segments inside the Petri dishes. Inoculation was performed by spraying the inoculum suspension on the leaves of wheat seedlings and on leaf segments, with four replicates.

\section{Incubation}

Soon after inoculation, seedlings and Petri dishes were kept in a growth chamber covered with dark plastic for 20 hours, providing favorable environment for infection $\left(20^{\circ} \mathrm{C}\right.$, relative humidity close to $100 \%$ in the dark). Following this period, plants and plates were kept in a growth chamber at $20^{\circ} \mathrm{C} \pm 2^{\circ} \mathrm{C}$ and $12 \mathrm{~h}$ photoperiod covered with transparent plastic until evaluation.

\section{Fungicide suspension}

Suspensions of the fungicides tebuconazole (Folicur $0.75 \mathrm{~mL} / \mathrm{L}$ distilled water) and azoxystrobin (Priori $0.25 \mathrm{~mL} / \mathrm{L}$ distilled water) were prepared in polyethylene flasks ( $2 \mathrm{~L}$ volume). Adjuvant (Tween 20) was added at $120 \mu \mathrm{L} / \mathrm{L}$ to the suspension to optimize leaf cover and avoid areas without deposition. In the control treatment, only distilled water and adjuvant was sprayed on both plants and Petri dishes (15).

Fungicides were applied with a manual atomizer equipped with a cone type nozzle.

Experimental design was in completely randomized blocks with four replicates both in vitro and in vivo.

\section{Time of fungicide application}

In the preventive treatment, fungicides were applied 24 hours before inoculation. Curative application, in latent infection, was performed four days after inoculation in post-penetration pre-symptom stages. Eradicative application was performed ten days after inoculation, in the post-symptom stage $(1,7,14)$.

Strobilurin and triazole are penetrating chemicals; thus, after application, both potted seedlings and leaf segments in Petri dishes remained in a mist chamber to slow the drying of droplets sprayed on the leaves. Petri dishes remained open to allow partial drying of fungicides applied on leaf segments. Subsequently, plastic pots with seedlings and Petri dishes with leaf segments were taken to the growth chamber.

\section{Assessment}

Fifteen days after inoculation, the number of uredia $/ \mathrm{cm}^{2}$, the number of spores/uredia and uredospore germination of MFT MT-4002S ('Ônyx') and T(F)P-HT races ('Quartzo') were assessed for curative and eradicative treatments. 


\section{Evaluation of uredospore germination}

Curative and eradicative effects of tebuconazole and azoxystrobin on MFT-4002S MT and T(F)P-HT races were quantified based on spore germination on the fifteenth day after inoculation. Three leaves per treatment were randomly collected for in vivo and in vitro experiments. Leaf segments were placed in glass tubes containing $4.0 \mathrm{~mL}$ distilled water and stirred to release the uredospores. A $0.5-\mathrm{ml}$ spore suspension was transferred to a Petri dish containing wheat leaf extract agar (10) and kept in the dark at $20{ }^{\circ} \mathrm{C}$ for $20 \mathrm{~h}$, and viability was quantified under an optical microscope (100x magnification). A uredospore was considered germinated when the germ tube was longer than the largest diameter of the spore.

\section{Statistical analysis}

Data were subjected to analysis of variance and the mean uredia/ $\mathrm{cm}^{2}$, uredospore number/uredium and in vivo and in vitro germination were compared according to Tukey's test at 0.05 .

The experiment was repeated twice using the same methodology.

\section{RESULTS AND DISCUSSION}

The chemical industry has produced a diverse range of new fungicides with different active ingredients and modes of action to control plant diseases. However, only two fungicide groups are recommended to control wheat leaf rust (11). Triazoles or DMIs (demethylation inhibitors) and strobilurin or QoIs (quinone outside inhibitors) are an important tool to control these diseases.

Despite considerable advances in the discovery, development and use of fungicides with broad spectrum and mode of action to diseases (8), the search for new modes of action remains constant due to the high dependence of global agriculture.

Azoxystrobin acts in the inhibition of mitochondrial respiration by blocking electron transfer between cytochrome $b$ and cytochrome $c 1$ at the QoI site, acting on ATP production. As germination requires energy, QoIs inhibit the germination of pathogenic fungi (2).

Tebuconazole belongs to the group of triazoles or DMIs, demethylation inhibitors, which act in the synthesis of ergosterol, the major component of fungal membranes, resulting in the accumulation of sterol precursors due to inhibition of the $\mathrm{C}_{14}$-methyl group removal from 24 methylene dehydrolanasterol. Fungal spores used for germination stored sterols. When exposed to DMI application, they do not inhibit germination but only interfere with the production of sterols required for fungal growth (8).

The detached leaf assay was efficient in testing leaf rust control by fungicides azoxystrobin and tebuconazole in preventive, curative and eradicative treatments.

In the control treatment, the first symptoms of leaf rust were observed on the fifth day after fungal inoculation. The first uredia were detected on the eighth day, while sporulation onset was noted on the tenth day after inoculation. In Petri dishes, a two-day delay in the signs and symptoms was probably due to the adaptation of leaf segments to the senescence retardant medium.

Fungicides (azoxystrobin and tebuconazole) applied as preventive treatment on leaves grown in pots and on leaf segments in Petri dishes controlled $100 \%$ infectious process (data not shown).

The effect of treatments on number of uredia $/ \mathrm{cm}^{2}$ (Table 1) reflected on the number of spores/uredia (Table 2).

Azoxystrobin was more potent than tebuconazole in inhibiting uredospore germination (Table 3).

Spore no. $/ \mathrm{cm}^{2}$ was a function of uredia no. $/ \mathrm{cm}^{2}$ and spore no./ uredia (Table 4).

Table 1. In vivo and in vitro sensitivity of Puccinia triticina races to fungicides applied as curative and eradicative treatments according to number of uredia $/ \mathrm{cm}^{2}$

\begin{tabular}{|c|c|c|c|c|c|c|c|c|}
\hline \multirow{3}{*}{ Treatments/ Mean } & \multicolumn{8}{|c|}{ Race } \\
\hline & \multicolumn{4}{|c|}{ MFT-HT } & \multicolumn{4}{|c|}{ MFP-HT 4002S } \\
\hline & Cura $^{y}$ & Eradic $^{2}$ & Cura & Eradic & Cura & Eradic & Cura & Eradic \\
\hline Azoxystrobin & $0.0 \mathrm{c}$ & $18.6 \mathrm{~b}$ & $0.0 \mathrm{c}$ & $16.0 \mathrm{a}$ & $0.0 \mathrm{c}$ & $17.7 \mathrm{a}$ & $0.0 \mathrm{c}$ & $14.8 \mathrm{~b}$ \\
\hline Tebuconazole & $1.0 \mathrm{~b}$ & $23.9 \mathrm{a}$ & $1.2 \mathrm{~b}$ & $12.1 \mathrm{~b}$ & $0.8 \mathrm{~b}$ & $18.2 \mathrm{a}$ & $1.1 \mathrm{~b}$ & $17.9 \mathrm{a}$ \\
\hline Control & $22.4 \mathrm{a}$ & $22.5 \mathrm{a}$ & $15.1 \mathrm{a}$ & $17.3 \mathrm{a}$ & $17.9 \mathrm{a}$ & $18.6 \mathrm{a}$ & $14.2 \mathrm{a}$ & $15.1 \mathrm{~b}$ \\
\hline
\end{tabular}

${ }^{\mathrm{v}}$ In vivo - potted wheat seedlings. ${ }^{\mathrm{x}}$ In vitro - wheat leaf segments in Petri dishes. ${ }^{\mathrm{y}} \mathrm{Cura}$ - curative application. ${ }^{\mathrm{z}}$ Eradic - eradicative application.

Table 2. In vivo and in vitro sensitivity of Puccinia triticina races to fungicides applied as curative and eradicative treatments according to number of spores/uredia.

\begin{tabular}{|c|c|c|c|c|c|c|c|c|}
\hline \multirow{3}{*}{ Treatments/ mean } & \multicolumn{8}{|c|}{ Race } \\
\hline & \multicolumn{4}{|c|}{ MFT-HT } & \multicolumn{4}{|c|}{ MFP-HT 4002S } \\
\hline & \multicolumn{2}{|c|}{ In vivo ${ }^{v}$} & \multicolumn{2}{|c|}{ In vitro ${ }^{x}$} & \multicolumn{2}{|c|}{ In vivo } & \multicolumn{2}{|c|}{ In vitro } \\
\hline \multicolumn{9}{|c|}{ Spore/uredia (no.) } \\
\hline Azoxystrobin & - & $233.1 \mathrm{~b}$ & - & $476.1 \mathrm{~b}$ & - & $215.0 \mathrm{~b}$ & - & $412.4 \mathrm{~b}$ \\
\hline C. V. $(\%)$ & 18.0 & 29.4 & 13.3 & 12.8 & 25.9 & 25.2 & 13.5 & 15.4 \\
\hline
\end{tabular}

${ }^{v}$ In vivo - potted wheat seedlings. ${ }^{\mathrm{x}}$ In vitro - wheat leaf segments in Petri dishes. ${ }^{\mathrm{y}} \mathrm{Cura}$ - curative application. ${ }^{\mathrm{z}}$ Eradic - eradicative application. 
Table 3. In vivo and in vitro sensitivity of Puccinia triticina races to fungicides applied as curative and eradicative treatments according to spore germination.

\begin{tabular}{|c|c|c|c|c|c|c|c|c|}
\hline \multirow{3}{*}{ Treatments/ Mean } & \multicolumn{8}{|c|}{ Race } \\
\hline & \multicolumn{4}{|c|}{ MFT-HT } & \multicolumn{4}{|c|}{ MFP-HT 4002S } \\
\hline & Cura $^{y}$ & Eradic $^{2}$ & Cura & Eradic & Cura & Eradic & Cura & Eradic \\
\hline Azoxystrobin & - & $24.7 \mathrm{c}$ & - & $18.2 \mathrm{c}$ & - & $30.7 \mathrm{~b}$ & - & $24.0 \mathrm{c}$ \\
\hline Tebuconazole & $71.7 \mathrm{~b}$ & $70.3 \mathrm{~b}$ & $65.0 \mathrm{~b}$ & $61.0 \mathrm{~b}$ & $71.7 \mathrm{~b}$ & $94.8 \mathrm{ab}$ & $52.0 \mathrm{~b}$ & $55.7 \mathrm{~b}$ \\
\hline Control & $99.0 \mathrm{a}$ & $97.3 \mathrm{a}$ & $84.7 \mathrm{a}$ & $83.0 \mathrm{a}$ & $98.0 \mathrm{a}$ & $98.0 \mathrm{a}$ & $65.5 \mathrm{a}$ & $80.0 \mathrm{a}$ \\
\hline
\end{tabular}

${ }^{\mathrm{V}}$ In vivo - potted wheat seedlings. ${ }^{\mathrm{x}}$ In vitro - wheat leaf segments in Petri dishes. ${ }^{\mathrm{y}}$ Cura - curative application. ${ }^{\mathrm{z}}$ Eradic - eradicative application.

Table 4. In vivo and in vitro sensitivity of Puccinia triticina races to fungicides applied as curative and eradicative treatment according to number of spores $/ \mathrm{cm}^{2}$.

\begin{tabular}{|c|c|c|c|c|c|c|c|c|}
\hline \multirow{4}{*}{ Treatments/Mean } & \multicolumn{8}{|c|}{ Race } \\
\hline & \multicolumn{4}{|c|}{ MFT-HT } & \multicolumn{4}{|c|}{ MFP-HT 4002S } \\
\hline & \multicolumn{2}{|c|}{ In vivo $^{\mathrm{v}}$} & \multicolumn{2}{|c|}{ In vitro ${ }^{\mathrm{x}}$} & \multicolumn{2}{|c|}{ In vivo } & \multicolumn{2}{|c|}{ In vitro } \\
\hline & Cura $^{y}$ & Eradic $^{z}$ & Cura & Eradic & Cura & Eradic & Cura & Eradic \\
\hline \multicolumn{9}{|c|}{ Spore/cm² (no.) } \\
\hline Azoxystrobin & - & $3,748.0$ & - & $7,617.6$ & - & $3,808.5$ & - & $6,103.5$ \\
\hline Tebuconazole & 655.5 & $6,292.8$ & 157,7 & $8,102.1$ & 711.0 & $12,250.4$ & $1,049.0$ & $7,938.6$ \\
\hline Control & $16,031,6$ & $16,044.7$ & $9,426.9$ & $22,567.8$ & $24,378.0$ & $25,500.6$ & $11,029.6$ & $21,417.8$ \\
\hline
\end{tabular}

${ }^{\mathrm{v}}$ In vivo - potted wheat seedlings. ${ }^{\mathrm{x}}$ In vitro - wheat leaf segments in Petri dishes. ${ }^{\mathrm{y}}$ Cura - curative application. ${ }^{ }$Eradic - eradicative application.

The overall effect in vivo compared to that in vitro, without fungicide, was as follows: uredia $/ \mathrm{cm}^{2}-20.5$ in vivo and 15.1 in vitro, spore number/uredia - 1,043.3 in vivo and 1,021.3 in vitro, spore germination $-98.5 \%$ in vivo and $82.3 \%$ in vitro, and spore number/ $\mathrm{cm}^{2}-20,765.8$ in vivo and 15,423.3 in vitro (Tables 1, 2, 3 and 4).

Considering the effect of races, uredia/ $\mathrm{cm}^{2}$ was 18.7 for race MFTHT and 16.8 for race MFP-HT 40002S, spore/uredia was 670.0 for MFT-HT and 1,394.7 for MFP-HT 40002S, spore germination was $91.8 \%$ for MFT-HT and $89.0 \%$ for MFP-HT $40002 \mathrm{~S}$, and spore $/ \mathrm{cm}^{2}$ was 12,729.3 for MFT-HT and 23,417.8 for MFP-HT 40002S (Tables $1,2,3$ and 4).

Comparing the effects of fungicides, uredia $/ \mathrm{cm}^{2}$ was 16.2 for azoxystrobin, 9.5 for tebuconazole and 17.8 for control, spore/uredia was 156.8 for azoxystrobin, 644.4 for tebuconazole and 1,032.3 for control, spore germination was $27.3 \%$ for azoxystrobin, $71.8 \%$ for tebuconazole and $90.4 \%$ for control, and spore $/ \mathrm{cm}^{2}$ was $4,956.0$ for azoxystrobin, 5,250.0 for tebuconazole and 18,094.2 for control (Tables 1, 2, 3 and 4).

The penetrating fungicide azoxystrobin effectively controlled latent infections by races MFT-HT more efficently than MFP-HT 4002S and was more efficient than tebuconazole, both in vivo and in vitro, against the tested races (Table 1).

MFT-4002S MT and T(F)P-HT races were less sensitive to triazole in curative and eradicative applications, also demonstrating their sensitivity reduction to tebuconazole, as shown by Arduin et al. $(1,3)$.

Regarding eradicative applications, there was a trend to higher control efficiency for azoxystrobin than for tebuconazole considering uredospore viability. Tebuconazole did not act efficiently in inhibiting uredospore germination. For race MFT MT-4002S, mean germination in vivo was $94.8 \%$ and $55.7 \%$ (Table 4), while for $\mathrm{T}(\mathrm{F}) \mathrm{P}-\mathrm{HT}$, mean germination was $70.3 \%$ and $61.0 \%$ in vivo and in vitro, respectively.

Regarding eradicative applications, there was a trend of higher control efficiency of azoxystrobin compared with tebuconazole, as to the spore viability. Tebuconazole did not act efficiently in inhibiting uredospores germination. For MFT-MT race, the average in vivo germination was $94.8 \%$ and $55.7 \%$ in vitro (Table 3 ). For race TFP-HT, the mean germination was $70.3 \%$ and $61 \%$, respectively.

To assess the viability of spores treated with azoxystrobin in the eradicative treatment, only the germ tube size was taken into account and not their abnormal morphological appearance. The germinated uredospore treated with strobilurin showed germ tube deformation. Such deformation probably does not succeed in the infectious process. No reference was found discussing the effect of strobilurin on Pt germ tube deformation.

The detached leaf method was efficient in assessing $P t$ sensitivity to fungicides, similarly to the reports by Felsenstein et al. (6) and Jackson et al. (9).

Azoxystrobin showed preventive action and 100\% control, both in vivo and in vitro, for races MFT-MT 4002S and T(F)P-HT. The curative effect of tebuconazole was little evident for both races.

Eradicative application of azoxystrobin was effective in controlling the number of uredia/ $\mathrm{cm}^{2}$, number of uredospores/uredia and spore viability, when compared to controls. For tebuconazole, eradicative control was little evident, compared to control.

Penetrating fungicides that are absorbed by the leaves have protective, curative and eradicative actions $(7,14)$.

The tested races remain sensitive to azoxystrobin and keep reducing sensitivity to tebuconazole according to tests in vivo and in vitro. 


\section{REFERENCES}

1. Arduim, F.S.; Reis, E.M.; Barcellos, A.L.; Turra, C. In vivo sensitivity reduction of Puccinia triticina races, causal agent of wheat leaf rust, to DMI and QoI fungicides. Summa Phytopathologica, Botucatu, v.38, n.4, p.306-311, 2012 .

2. Bartlett, D. W.; Clouch, J. M.; Godwin, J. R.; Hall, A. A.; Hamer, M.; Parr-Dobrzanski, B. The strobirulin fungicides. Pest management Science, New Jersey. v.58. p. 649-662. 2002.

3. Bianchin, V. Especialização fisiológica de Puccinia triticina, agressividade e sensibilidade de raças a fungicidas. Tese (doutorado em Agronomia/Fitopatologia) - Faculdade de Agronomia e Medicina Veterinária, Universidade de Passo Fundo, 139 p. 2011.

4. Chaves, M.S. and Barcellos, A.L. Especialização fisiológica de Puccinia triticina no Brasil em 2002. Fitopatologia Brasileira, Brasília, v.31, n.1, 57-62 p. 2006

5. Companhia Nacional de Abastecimento - CONAB. Acompanhamento das Safra Brasileira, Safra 2010/2011. Disponível em: http://www.conab.gov. br> Acesso em 03 dez. 2013.

6. Felsenstein, F. G.; Park, R. F. and Zeller, F. J. The use of detached seedling leaves of Triticum aestivum to study pathogenicity in Puccinia recondita $\mathrm{f}$. sp. tritici. J. Phytopathology, St, Paul, n. 146, p. 115- 121. 1998.

7. Godoy, C.V.; Canteri, M.G. Efeitos protetor, curativo e erradicante de fungicidas no controle da ferrugem da soja causada por Phakopsora pachyrhizi, em casa-de-vegetação. Fitopatologia Brasileira, Brasília, DF, v.29, p.97-101, 2004.

8. Hewitt, H. G. Fungicide in crop protection. CAB Internacional, p. 87-153. 1998.

9. Jackson, E. W.; Obert, D. E. ; Chong, J.; Avant, J. B.; Bonman, J. M. Detached-leaf method for propagating Puccinia coronata and assessing crown rust resistance in oat. Plant Disease, St. Paul, v. 92, n. 1400-1406. 2008.

10. Reis, E. M.; Richter, R. Efeito de substratos sobre a germinação de uredosporos e comprimento de tubos germinativos de Puccinia triticina. Fitopatologia Brasileira, Brasília, DF, v. 32, n. 1, p. 75-78, 2007.

11. Reunião da comissão brasileira de pesquisa de trigo e triticale. Informações técnicas para trigo e triticale - safra 2016/9 Reunião da Comissão Brasileira de Pesquisa de Trigo e Triticale; Gilberto Rocca da Cunha, Eduardo Caierão e André Souza Rosa, ed. Técnicos - Passo Fundo, RS: Biotrigo Genética, 2016. 228 p.

12. SamborskI, D. J. Wheat Leaf Rust. In: ROELFS, A. P. \& BUSHNELL, W. R. (Eds.). The cereal rust-Disease, distribuition, epidemiology and control. Orlando (Florida): Academic Press. v. 2, p. 39-59. 1985.

13. Zadoks, J. C.; Chang, T. T.; Konzak, C. F. A decimal code for the growth stages of cereals. Weed Research, Oxford, v.14, n.6, p. 415-421, 1974.

14. Reis, E. M.; Zanatta, T.; Zanatta, M. Curative and eradicant action of fungicides to control Phakopsora pachyrhizi in soybean plants. Summa Phytopathologica, Botucatu, v.42, n.4, p.295-302, 2016.

15. Zanatta, T.; Reis, E.M. Adjuvant concentrations and uredospore densities on Phakopsora pachyrhizi infection efficiency in soybean. Summa Phytopathologica, Botucatu, v.38, n.2, p.148-151, 2012. 